\title{
"Mother" in Aytül Akal's Stories within the Context of Social Gender Perception
}

\author{
Oğuzhan Yılmaz ${ }^{1} \&$ Yasin Mahmut Yakar $^{2}$ \\ ${ }^{1}$ Faculty of Education, Erzincan University, Erzincan, Türkiye \\ ${ }^{2}$ Faculty of Education, Erzincan University, Erzincan, Türkiye \\ Correspondence: Oğuzhan Yilmaz, Faculty of Education, Erzincan University, Erzincan, 24000, Türkiye. Tel: \\ 90-50-6420-7602
}

Received: March 4, 2016

Accepted: April 5, 2016

Online Published: April 7, 2016

doi:10.5430/ijhe.v5n2p213

URL: http://dx.doi.org/10.5430/ijhe.v5n2p213

\begin{abstract}
Just as many factors are of question in one's identity, so is the way to present the characters in literary books. Presentation of characters on equality basis is very important so that democratic culture and human rights related values are acquired. In this study, mother image fictionalized by Aytul Akal in her stories of children is dealt with in terms of social gender. The study was conducted through document analysis design. We have reached and examined all of the story books written by Aytul Akal for children. Nine of these books were written by Aytul Akal herself while only two in cooperation with Mavisel Yener. The data were collected based on studies on social gender and researches on quality of children's books during literature review then the data collected were classified for archival reasons while they were classified for purpose of record. Secondly, story books written by Aytul Akal for children were examined and the image of father and mother were encoded and recorded by two researchers and one qualitative research specialist. The data analyzed descriptively were exposed to content analysis for detailed information. As a result, it was found that the character attributes on image of mother in Aytul Akal's works were closely related with her roles in home and work life. Since mother was as someone dealing with home work, children and work, from time to time she experienced difficulties. This shows that traditional image or understanding of mother in the stories did not essentially change and the workload of mother was stable while her work outside home increased. The present study aims to assess the mother image in Aytul Akal's stories based on the social gender perspective.
\end{abstract}

Keywords: Social gender perception in literary texts, Aytul Akal, Mother image

\section{Introduction}

In forming one's own identity, a good many factors are taken into consideration as well as the way characters are presented in literary books. Presentation of characters on equality basis is of great importance in terms of obtaining democratic culture and human rights. Therefore, in the present study, the image of mother in the stories for children by Aytul Akal has been treated within the context of social gender. In spite of a good many works on social gender in cartoons, toys and textbooks, the idea that implicit and explicit messages related to social gender are key players in identity formation and that very few studies have been reported on this topic in literary children's books have been effective in penning this paper. The present study is to contribute to international researches on social gender previously conducted from Turkish perspective.

Social gender defined as physical description and division of bodies encoded biologically and giving them spiritual meanings (Bingöl 2014: 108) intend to explain roles, responsibilities and socially designated attributes of man and woman (Vefikuluçay et al. 2007:27; Yogev 2006). In contrast to biological gender, this phenomenon constructed and modified due to social structure shows up as an image of a wide-range of social division of labour because of cultural, religious and ideologic consolidation of systems (Ostergaard 1992).

Social gender reveals its effect in due course, determines certain roles and is internalized by the society in which it has developed (Seçgin \& Tural, 2011). For example, pilot and surgeon are perceived as male professions while kindergarten teacher, nurse or steward/stewardess are assumed to be female (Bahsin 2003: 45). Similarly, women are traditionally expected to cook, wash dishes, look after children and clean the house while men are to be breadwinners and occupied with works like mending and gardening (Şafak, Çopur, Özkan 2006). This expectation leads in time to 
inequality between genders as indicates Bingöl. The values, roles and patterns attributed to man and woman based on social gender are hierarchically discriminatory since man is "superior and leading" while woman is regarded as other because of her gender socially determined (2014:113).

Although today woman is able to take part in work life and find more space in social life for herself, her increasing responsibilities result in new problems. In an environment where traditional roles have not changed but on the contrary dominated in family relations, work of woman outside home has added another load on her responsibilities (Ersoy 2009: 217). As Güzel states, though an ideal woman is modern, this does not necessarily mean that she is to be away from protecting traditional values. In one sense, she is expected to be a mother, businesswoman and at the same time a homeworker and play these socially identified roles (2014:191).

The findings that woman faced with difficulties in society as a result of the roles assumed in accordance with traditional understanding increases the load on her shoulders in modern life are supported by the relevant literary works. For example, according to research findings obtained by Özçatal (2011), women in spite of a paid job are to take responsibility of homework. In the study conducted by Eken (2006) in which the professional and family roles of women who work in the Turkish army have been examined, it is clearly stated that since they have to work both at home and in the workplace, the workload of women is more than that of men. Indeed, the present mentality needs change depending on human honor and equality basis. Everybody is of the opinion that people have juridically, politically, socially and morally equal rights and indiscriminately equal values (Kalayc1 2015: 244). As is widely known, it is one of the fundamental responsibilities of democracy to impede sex discrimination and ensure equality (Balkır 2013).

The change in roles attributed to woman by the society, libertarian steps to be taken for the sake of woman depend on several variables at this point. Family, friends, school, mass media, text books are only some of them (Powell and Greenhause 2010: 1012; Dökmen 2010: 18; Kuzgun and Sevim 2004: 16; Özkan 2013: 618; Tietz 2007). In this study, literary children's books thought to have an effect on social gender perception are discussed.

One of the ineluctable elements of literary children's books penned in order to "develop perception, feeling and thought of children and help them acquire sensitivity to human-being (Sever 2010, 140)" is character. "Character defined as the personage treated in terms of emotion, thought, behavior and passion in literary works such as novel, narratives and dramas (Püsküllüoğlu, 1994: 582) influences child reader and becomes a role-model for him. Characters become friends that child communicates from the very moment he meets the book (Aliye Erdem 2011: 614) and help child acquire his identity thanks to this friendship (Kırıtoğlu Özdil 2011: 412; Kanat Soysal 2011: 636, Aykaç and Türkoğlu 2011: 182; Karatay 2011: 473). As Baş states, the character intertwines with child (2011: 303), being on his tucker-bag and school bag, cup, notebook, book case, shoes, dress, bed, quilt, wall in his room, toys, computer desktop and on other objects and places and as a result leave a deep impact on his life (Zivtçi 2006: 246). The personage being an example for the child in many respects and helping him develop personality should enounce equalitarian discourse to avoid moulding children in the future. According to the argument of Vannicopulou, relative lack of female characters in books limits identification with their social genders, possibility of having a role in the society and prevents them from finding interesting female protagonists (2004: 70). In addition, Gooden and Gooden (2001: 89) stated an adverse effect of female roles dependent on social gender in child books on child reader. However, in spite of findings, general literature suggests that the roles as regards social gender in literary child books are not cast from egalitarian perspective.

For instance, Günindi Ersöz (2010) who examines the roles of social genders in terms of woman in Turkish proverbs and idioms states that Turkish society expects such indoor roles from woman as to be skilled, good at houskeeping, well-mannered, thrift in food and responsible for her husband and children. In other words, he suggests that the society seeks to create "good wife" and "good mother" from woman. Similarly, Akbalık (2013) in his study on gender perception in Turkish proverbs emphasizes that the most important gender role of woman is "wife" and "mother". Akbalık points out that since family is represented by means of woman, in proverbs wife is dominant rather than husband and mother is preeminent rather than father. He also cites that considering the role of mother in terms of proverbs, woman is after all taken into consideration with regards love and affection and is right-owner on human-being after the creator according to the proverbs. Özkan and Gündoğdu (2011) in their study on proverbs and idioms within the context of social gender argued that the distinction between male and femal children is obvious and that while girls are frequently remembered with marriage, share of the same destiny with mother, pressure and help with mother, boys are to contribute to earning living, maintain father's profession and be the source of proud and manliness.

As in proverbs, researches have also been reported, which examine social gender roles in advertisements. Özdemir 
(2010), for instance, who studies social genders in advertisements in Turkey alleges that men are generally represented in the advertisements as the father of the house while women are more as mother dealing with cuisine and child maintenance. Unlike the findings of Özdemir, Güzel (2014) in his study on the role of media in social gender based discrimination draws attention to the fact that in the advertisements woman is regarded either as a mother and wife or beautiful, attractive sex object with a low-level education.

Studies have been reported on related social gender roles in cartoons and computer games. Kalayc1 (2015) who analyzes the cartoon named Pepee from the perspective of social gender equality found that although all of the activities shown in the cartoon could be fulfilled by both woman and man, female characters were doing such activities as watering flowers, preparing food, dealing with baby while men were doing such activities that needed skills as driving and cycling. Kalaycı indicated messages in all episodes of the cartoon that could lead to inequality in social gender from colors to types of dress, emotional conditions to games played. Kan (2012) adds in his study on the creation of social gender in computer games that woman is shown as passive and secondary.

Like cartoons and computer games, textbooks are also effective in creating roles concerning social gender and contain implicit messages, explicit words and imagination on gender roles (Tietz 2007). Indeed, Özkan (2013), who studies woman in textbooks, states obvious sex discrimination in visual elements. Similarly, Kırbaşoğlu Kılıç and Eyüp (2011) in their research on social gender roles in primary school Turkish textbooks found sex discrimination. According to the findings of the study, the number of professions attributed to man was more than that allocated fro women. In the same study, regarding indoor roles, while women are dealing with food and children, men are occupied with mending and earning a living.

Inadvisable messages exist in literary child books on social gender equality as in textbooks. In his study on woman characters in pictured child books, Vannicopulou (2004) found that mother has the fundamental responsibility for raising children and acts like a service maid in the house and women are seen indoor or in places where they assume role of mother and housewife alike. Like these findings, Hamilton et al. (2006) in their studies argued that female characters deal with child education more than male ones and they are seen more indoor scenes rather than outside. Besides, they found that women contributed less to professional life compared to men and in the pictured books for both children and adults discrimination persisted. Gooden and Gooden (2001) in their research discovered that although the proportion reserved for women as protagonists in books increased compared to previous years, traditional roles given remained stable. Brugeilles et al. (2002) uncovered that the characters in books obviously varied based on gender and even presentation of animal characters in pictured child books suggested differences depending on gender. While in these books it is possible to see an inter-gender balance, there is a lack of representation of adult female characters in literary works. In the research, women assumed the role of mother however men did not have the role of a father.

As clearly seen in the relevant literature, in spite of the studies on social gender, the number of works on literary child books related to social gender is limited in Turkey. In the present paper, considering the gap in the relevant literature specifically in Turkey, from the fact that the groovy social gender roles in literary books forced both genders and women were confined to passive and trivial roles (Vannicopulou 204: 70), we tried to examine the mother image based on social gender in Aytul Akal's stories.

\section{Method}

Document analysis design was used in the study. Document analysis is used to analyze written documents on the phenomena examined. The design could be a research design on its own or it could be used as a supplementary source of information for other designs (Yıldırım and Şimşek, 2011: 187). In such researches, seeing that the data needed are obtained without observation or interview, document analysis is useful in that it contributes to the researcher in terms of time (Bowen 2009: 27).

\subsection{Sample}

In the study, all of the stories of Aytül Akal on children were examined. Nine of the books were written by Aytül Akal herself while two were composed in cooperation with Mavisel Yener. The information on the books examined is as follows: 
Table 1. The works of Aytül Akal

\begin{tabular}{|c|c|c|c|c|}
\hline Author & Name of the Book & $\begin{array}{l}\text { Year of } \\
\text { Publication }\end{array}$ & Publishing House & Abbreviation \\
\hline Aytül Akal & $\begin{array}{l}\text { Kizım Nerdesin (Where are } \\
\text { you my daughter?) }\end{array}$ & 2009 & Uçanbalık & $\mathrm{KN}$ \\
\hline Aytül Akal & $\begin{array}{l}\text { Kızım Ben Çocukken (My } \\
\text { daughter when I was a } \\
\text { child) }\end{array}$ & 2010 & Uçanbalık & $\mathrm{KBC}$ \\
\hline Aytül Akal & $\begin{array}{l}\text { Annem Neden Çıldırdı } \\
\text { (Why my mom got crazy?) }\end{array}$ & 2011 & Uçanbalık & ANÇ \\
\hline Aytül Akal & $\begin{array}{l}\text { Benim Babam Sihirbaz (My } \\
\text { father is a magician) }\end{array}$ & 2011 & Uçanbalık & BBS \\
\hline $\begin{array}{l}\text { Aytül Akal, Mavisel } \\
\text { Yener }\end{array}$ & $\begin{array}{l}\text { Kirmızı Şemsiye (Red } \\
\text { Umbrella) }\end{array}$ & 2011 & Uçanbalık & KŞ \\
\hline Aytül Akal & $\begin{array}{l}\text { Oğlum Nerdesin (Where are } \\
\text { you, my son?) }\end{array}$ & 2012 & Uçanbalık & $\mathrm{ON}$ \\
\hline Aytül Akal & $\begin{array}{l}\text { Oğlum Ben Çocukken } \\
\text { (My son when I was a child) }\end{array}$ & 2012 & Uçanbalık & ONÇ \\
\hline Aytül Akal & $\begin{array}{l}\text { Babamın Sihirli Küresi (My } \\
\text { father's magic globe) }\end{array}$ & 2014 & Tudem & BSK \\
\hline Aytül Akal & $\begin{array}{l}\text { Babam Duymasin (Do not } \\
\text { let father hear) }\end{array}$ & 2014 & Tudem & $\mathrm{BD}$ \\
\hline Aytül Akal & $\begin{array}{l}\text { Gökyüzünde Balonlar } \\
\text { (Balloons in the sky) }\end{array}$ & 2014 & Redhouse Kidz & GB \\
\hline $\begin{array}{l}\text { Aytül Akal, Mavisel } \\
\text { Yener }\end{array}$ & $\begin{array}{l}\text { Öykü Yazmayı Seviyorum (I } \\
\text { love writing stories) }\end{array}$ & 2014 & Bilgi & ÖYS \\
\hline
\end{tabular}

\subsection{Data Collection}

The data of the study were collected from two sources. First, previous studies were examined, dealing with literary child books on social gender. As a result, the information gathered was classified after card-index. Secondly, the story books written by Aytul Akal on children were investigated and mother and father characters in these books were encoded and card-indexed by two researchers and one qualitative research specialist. The data were card-indexed by different people to make the study more reliable in terms of encoding. In addition, encoding the characters in the role of father is to have a view on the attributes of mother character from a broad perspective.

\subsection{Data Analysis}

Following descriptive analysis of the data collected, content analysis was conducted in order to get detailed information. By means of content analysis, the points and themes not determined in the study before were revealed (Yıldırım and Şimşek 2011: 223). In this respect, mother image was examined under such headings as character attributes and roles she undertakes at home and at work. Since the study is a thematic research, some encodings could be classified under more than one caterogy, which is the most distinguishing limitation.

In order to ensure reliability between the coders, time based reliability test was conducted, which means assessment of the data in the same way at any time. Also, an observation based reliability test was done for more than one researcher to assess a phenomenon or event at the same time (Yıldırım and Şimşek 2011, 260). According to Miles and Huberman's formula (1994), the result of the time-based reliability test was found .90 while observation based reliability test yielded to .82 . These results suggested that encoding was reliable. 


\section{Results}

Table 2. Character Attributes of Mother

\begin{tabular}{|c|c|c|c|}
\hline $\begin{array}{l}\text { Positive Character } \\
\text { Attributes }\end{array}$ & $\begin{array}{l}\text { Negative Character } \\
\text { Attributes deriving from } \\
\text { extremity }\end{array}$ & $\begin{array}{l}\text { Generation conflict } \\
\text { based character } \\
\text { Attributes }\end{array}$ & $\begin{array}{l}\text { Intellectual Character } \\
\text { Attributes }\end{array}$ \\
\hline Thoughtful & Concerned & Astonishment & Writing stories \\
\hline Conciliator & Protector & Surfeit & Writing poems \\
\hline Persuasive & Interested & Straddle & Drawing a painting \\
\hline Diligent & Supervisory & Acquiesce & Master in a foreign language \\
\hline Sensitive & Interventionist & $\begin{array}{l}\text { Showing conflicting } \\
\text { conduct }\end{array}$ & Reading books \\
\hline Devoted & Prescriptive & & \\
\hline Tolerant & Hortative & & \\
\hline \multicolumn{4}{|l|}{ Hospitable } \\
\hline Sportive & & & \\
\hline
\end{tabular}

As is seen in Table 2, the first character attribute of mother is positive. In the work, the mother acts as conciliator between two siblings by talking to both of them (OBÇ, 54-55). She seeks to be tolerant (KBÇ, 38), sensitive for the problems around her (GB, 105), shows up as devoted $(\mathrm{ON}, 56)$ and hospitable $(\mathrm{GB}, 110-112)$ in front of the reader. Also, as a hardworking person, she executes her profession not "to be retired but to be successful and be beneficial $(O N, 67)$ ". Mother sometimes works so much that even her children find it strange (BD, 23).

The author accredits some intellectual qualities to mother as a support of her positive attributes. For example, mother knows two foreign languages (BSK, 47), reads books (OBÇ, 27), plans to write stories (KN, 21), draws pictures (ÖYS, 20) and is keen on poems. The mother, restricted to writing poems when young, learns to write in gloom in order to hide writing and does not help herself from writing poems during the nights when she pretends to sleep (KN, 42-43).

The mother in Aytul Akal's stories does not always come up with her positive attributes. Not idealizing the character, Akal refers some negative personality attributes to mother seen in real life. Mother generally distresses children by exaggerating some of her conduct. She continuously surveils them (ON, 9), asks too many questions related to children's private lives $(\mathrm{ON}, 7)$, and limits her children to a series of rules. For instance, she does not allow child to take the beanie to school, knitted by her grandmother.

Ironically! My mom did not let me bring my beanie to school... she said it was so flashy and it could be shameful. I do not understand, this is why I love it: flashy... It shows me older. When I wear it and walk, i feel like the leading actor in the serials (BSK, 8).

Mother sometimes becomes overprotective in the stories, concerned about her children and therefore limits their liberty. Calling frequently her daughter that goes to the cinema, she restricts her watching movies (ON, 9). She tries to monitor her daughter listening to music in the room by eavesdropping and does not keep herself from inappropriate conduct in order to learn what her daughter is doing $(\mathrm{KN}, 87)$ In the works whatever it is, she never resorts to violence as seldomly does father. (BBS, 59).

Mother experiences also conflict of generation with her children in the stories. The mother who is not able to make sense of what her children do sees disharmony between what she knows and the conduct of her children and therefore shows incoherent behavior. This leads to the feeling of in-between and exhaustion. The mother always faced with the reprimands of her children like "Don't be foolish mom, this is rubbish mom" (ON, 71), compares her period with that of her children and reproaches saying "where is my age gone? $(O N, 71)$. Different in many respects from her children, the mother does not manage to come to terms with them. For example, when she was a child, she was eating half doughnut but she finds it strange her child's eating hamburger and she does not like gelled hair covering the entire forehead of the child and offers him a new style. However, she is even more surprised when she gets such replies from the child upon this offer "Don't be foolish mum! That kind of style, I bet you seen in an archeological museum on one of the sculptures. There is nowhere in the World where you could see such hair style $(O B C,, 11-13)$ !' The mother that is not somewhat able to adapt herself to the time, is not only surprised but also anxious $(\mathrm{ON}, 17)$. 
Table 3. The role of mother at home

\begin{tabular}{lll}
\hline Indoor roles & Roles in looking after child & Home related roles \\
\hline $\begin{array}{l}\text { Kneading } \\
\text { Clear the table }\end{array}$ & $\begin{array}{l}\text { Taking the kids to the gym } \\
\text { Taking care of education of } \\
\text { children } \\
\text { Taking care of their nourishment }\end{array}$ & $\begin{array}{l}\text { Paying the bills } \\
\text { Shopping }\end{array}$ \\
$\begin{array}{l}\text { Laundery } \\
\text { Sewing }\end{array}$ & Taking care of their health & \\
Cooking cake & & \\
Cooking & & \\
Tidy up the rooms & & \\
Hosting guests & & \\
\hline
\end{tabular}

The indoor roles of mother are given in Table 3 . In the work, the mother is generally characterized with her indoor roles. She, as in traditional understanding of mother, kneads doughs (GB, 61), sets the table (BD, 32), does laundery (BBS, 16), sews and cooks (KN, 19-20), (OBÇ, 17). For instance, "My mum was making squares and round stars using the usual moulds $(G B, 61)$.", “When the sun starts to go back home, my elder sister and I were helping mum with setting the table (BD, 32).", "Ehh, you guys live with your mum alone, don't you? When she does not sew, who takes care of the house (GB, 105).", "we should rap the cat over the knuckles! Will I clean mud everyday (ANC,, 12)?", "Mum, I am so starving $(O B C$, 17)." points out how busy the mother is with indoor works. In spite of active role of the mother indoor affairs, father seldomly sets the table (GB, 112), cooks and (ANÇ, 69) takes over the home affairs that require force $(\mathrm{BD}, 12)$.

The mother in the relevant works takes nearly full responsibility for the child as well as for home affairs such as cleaning, washing dishes, cooking. She also implements the passive role of the father showing renunciant behavior and taking them to gym (GB, 23), dealing with their education (ANÇ, 6), food (GB, 87) and health (BD, 12). In the work do not let father hear, that she poises over her sick child anxiously until morning without any sleep and that she says to the child that she cannot give him/her any chocolate, nuts, candies, icecream etc just because the doctor does not let them are signs that the mother is taking care of the children (BD, 12). Another sign is seen in the work the balloons in the sky. The mother that has eyes on the child continuously states "Sit up right, do not eat olives with your hands, look there is the fork. Look at the mirror; you are in a mess" in order to correct the behavior of the children $(G B, 85)$."

The roles of mother in the works are not limited to child and home affairs. Mother takes responsibility for home related affairs though not as much as father. In this respect, her obvious roles in the works are to buy bread (OBÇ,19), pay the bills (ON, 76). Even sometimes, she experiences a series of conflicts herself on the roles she takes over. When she is talking to her son, she scolds her saying "so you think my responsibilities are so few, don't you? Indeed, there is a lot of work to bear in mind and complete...from which one should I start to say? The bills? School payments, credit cards?; janitor's dues, heating bill, mortgage checks; pharmacy, dress, shopping; mending the rummage $(O N, 76)$ ? “, which are obviously the signs of heavy workload of mother.

Table 4 . The role of mother at work

\begin{tabular}{ll}
\hline Profession & Work related activities \\
\hline Child Education Specialist & Participation in seminar \\
& Business meeting \\
& Business lunch \\
Continuous workload \\
Taking care of dressing
\end{tabular}

The work related roles of the mother are given in Table 4. As could be understood from the statement "Mum, don't you remember I am child education specialist $(O N, 71)$ !'” the mother works as a child education specialist. Although the work related life of the mother seems to be limited to indoor activities, the books of Akal suggest that she participates in the seminars (BBS, 48), business meetings and business lunches (BSK, 48). Indeed, such activities are given generally indirectly as in the statements "Do you think I can go to work in such dress? Or participate in a meeting? Thus, even at this age, everybody would look at me and I would draw attention (ON, 41)." 


\section{Discussion and Conclusion}

In the present study, the mother image in Aytul Akal's works for children was examined and the roles of mother, which are related to home and work as well as her attributes are of most concern.

The woman that is on the forefront in the stories with her attributes generally represents a mother in the stories as stated in the works of Brugeilles et al (2002). The mother in this study has positive character attributes such as self-sacrificing, diligent and tolerant. In the present research, several qualities classified under the negative character attributes are generally the conduct that comes out unintentionally and out of love. Considering this aspect of mother, the woman in general and mother in particular is regarded in terms of love and affection in the relevant literature (Akbalık 2013). Vannicopulou (2004) in his study pointed out that woman and mother, who never spare her love, interest and care in spite of her secondary and ordinary role and who could be narrated in the books for pages are seen in terms of love. Another point that is closely related to mother's character is a continuous conflict of generations with her children. Such frequent statements of mother as "In my childhood, they would play disks, there were no ipods. We would listen to our music by tuning the radio or through a long length tape recorders...I never had a bike, desk or bookshelf (OBC, 9)." may be due to the fact that technology advances swiftly and children have better opportunities. Another variable that would lead to the conflict of generations would be that books were written for the children. In Akal's stories, mother is depicted with some intellectual attributes. The mother image that Akal characterizes has a tendancy toward story, poem and art although not being able to spare time from her work and home. Although in her stories such attributes of mother are given more decoratively as is clear in the statement "your mom has two languages and I have three; we would conquer the world (BSK, 47)", they are important in that they suggest that mother can read and know a foreign language. From the point of view, Akal's works do not correspond to the findings in the literature.

The role of mother at home affairs is one of the distinguishing attributes in the works. The mother showing up in the stories before the reader with her traditional roles kneads doughs, sets the table, cooks and does laundery. Taking into consideration the relevant literature, no change in this situation is seen. In many studies on social gender in proverbs, publicity, computer games and textbooks, mother or woman is put in a secondary position, her roles are limited to preparing the table, cleaning the house and culinary (Günindi Ersöz 2010; Özdemir 2010; Kalayc1 2015; Kırbaşoğlu Kılıç and Eyüp, 2011; Gooden and Gooden, 2001). This would result from acquiescence due to male dominant opinion and the residue of thought created for years. One of the difficult tasks of woman is to raise children. Compared to father, the mother found to deal with more with children in the works about several issues from nutrition to education of children. Considering the literature, this point suggests that the role of woman is more motherness (Günindi Ersöz 2010; Akbalık 2013, Özdemir 2010; Kırbaşoğlu Kılıç and Eyüp 2011; Vannicopulou 2004; Hamilton vd. 2006). Indeed, the children are not only mothers but also fathers who should equally cope with the problems and needs of children in education and in other fields. In the works investigated, it is clear that though the father is not indifferent to his children, most of the responsibility is mothers. In this respect, except for home affairs, she takes the responsibility for such works as paying the bills, shopping for home, dress and janitor's dues. Though the father assumes these roles in the stories, the father image in realisation of implementing the indoor roles is not as much active. This leads to increase in the workload of mother and decrease in that of father although it is different from the traditional understanding that outdoor roles are fathers while indoor roles are mothers.

In Akal's works, roles of mother at work are also given. In the stories, mother is a child education specialist. But this profession and the activities of mother related to this occupation seem to take place as a decorative factor in the stories. For mother does not/cannot use her experiences related to her work in relations with her children. In the stories, the mother having conflicting ideas with the children exposes most of the time inconsistent conduct and intervenes lifestyle of her children. Another point that is worth mentioning is that the work related routines such as participation in seminar and business lunch, business meetings are frequently discussed at home. For instance, in one of the works, the statement of mother "Do you think I can go to work in such dress? Or participate in a meeting? Thus, even at this age, everybody would look at me and I would draw attention"(ON, 41) It is important to find out how woman and mother image is fictionalized by the fact that the mother that should come in the forefront with her experience and knowledge expresses herself with her dress and wants to draw attention of people with that dress. This finding overlaps the research of Güzel (2014) on the role of media that woman with a low-level of education is a sex object. In the stories of Akal for children, the traditional understanding of woman has not changed based on the fact that the mother is never in a social environment related to her work and that work related points are given between the lines and supposing that "mother works".

As a result, the mother attributes in Aytül Akal's works generally stand out with her home and work related roles. In the relevant works, mother is depicted as homeworker, child carer and worker outside home therefore she has difficulties. This shows that traditional image of woman/mother does not change in Akal's stories and her workload increases outside home although stable at home. In this respect, the following suggestions would be of use for 
fictionalized stories for children in general and Akal's stories in particular:

1. The responsibilities of mother and husband indoor and outdoor should be distributed evenly.

2. The roles of female characters related to work should not remain decorative instead they should be in the forefront in work life with their experiences.

3. Since the characters in imaginative texts for children are a role-model, they should not create stereotypes toward social gender.

4. Increasing the number of such books on social gender should create an awareness of the woman.

5. Authors of children's books should avoid sex discrimination while paying attention to the role and place of woman in the society.

\section{References}

Akal, A. (2009). Kızım nerdesin. Uçanbalık Yayınları: İzmir.

Akal, A. (2010). Kızım ben çocukken. Uçanbalık Yayınları: İzmir.

Akal, A. (2011). Annem neden çıldırdı. Uçanbalık Yayınları: İzmir.

Akal, A. (2011). Benim babam sihirbaz. Uçanbalık Yayınları: İzmir.

Akal, A. (2012). Oğlum ben çocukken. Uçanbalık Yayınları: İzmir.

Akal, A. (2012). Oğlum nerdesin. Uçanbalık Yayınları: İzmir.

Akal, A. (2014). Babam duymasın. Tudem Yayınları: İzmir.

Akal, A. (2014). Babamın sihirli küresi. Tudem Yayınları: İzmir.

Akal, A. (2014). Gökyüzünde balonlar. Redhouse Kidz Yayınları: İstanbul.

Akal, A. ve Yener, M. (2011). Kırmızı şemsiye. Uçanbalık Yayınları: İzmir.

Akal, A. ve Yener, M. (2011). Öykü yazmayı seviyorum. Bilgi Yayınevi: Ankara.

Akbalık, E. (2013). Türk atasözlerinde cinsiyet algısı. Dumlupınar Üniversitesi Sosyal Bilimler Dergisi. 36. 81-90.

Aykaç, N. Ve Türkoğlu, İ. E. (2011). Çocuk ve gençlik edebiyatı bağlamında Montaigne'in denemelerinin eğitbilimsel değerler açısından değerlendirilmesi. 3. Ulusal Çocuk ve Gençlik Edebiyatı Sempozyumu içinde (s. 181-190). Ankara: Ankara Üniversitesi.

Bahsin, K. (2003). Toplumsal cinsiyet. Kadınlarla Dayanışma Vakfı Yayınları: İstanbul.

Balkır, Z. G. (2013). Kadın kitabı. Umuttepe Yayınları: Kocaeli.

Baş, B. (2011). Çizgi filmlerdeki iletiler üzerine bir değerlendirme. 3. Ulusal Çocuk ve Gençlik Edebiyatı Sempozyumu içinde (s. 301-306). Ankara: Ankara Üniversitesi.

Bingöl, O. (2014). Toplumsal cinsiyet olgusu ve Türkiye'de kadınlık. KMÜ Sosyal ve Ekonomik Araştırmalar Dergisi. 16/1. 108-114. http://dx.doi.org/10.18493/kmusekad.36760

Bowen, G. A. (2009). Document analysis as a qualitative research method. Qualitative research journal. 9/2. 27-40. http:// emeraldinsight.com (erişim tarihi: 26.10.2015).

Brugeilles, C., Cromer, I. ve Cromer, S (2002). Male and female characters in illustrated children's books or how children's literature contributes to the construction of gender. Population. 57/2. 237-267. http://dx.doi.org/10.2307/3246609

Dökmen, Z. Y. (2010). Toplumsal cinsiyet sosyal psikolojik açıklamalar. Remzi Kitabevi: İstanbul.

Eken, H. (2006). Toplumsal cinsiyet olgusu temelinde mesleğe ilişkin rol ile aile içi rol etkileşimi: Türk silahlı kuvvetlerindeki kadın subaylar. Selçuk Üniversitesi Sosyal Bilimler Enstitüsü Dergisi. 15. 247-280.

Erdem, A. (2011). İlköğretim öğrencilerinin bakış açısıyla çocuk kitaplarındaki kahramanlar. 3. Ulusal Çocuk ve Gençlik Edebiyatı Sempozyumu içinde (s. 613-620). Ankara: Ankara Üniversitesi.

Ersoy, E. (2009). Cinsiyet kültürü içerisinde kadın ve erkek kimliği (Malatya örneği). Fırat Üniversitesi Sosyal Bilimler Dergisi. 19/2. 209-230.

Gooden, A. M. ve Gooden, M. A. (2001). Gender representation in notable children's Picture books: 1995-1999. Sex Roles. 45. 89-101. http://dx.doi.org/10.1023/A:1013064418674

Günindi Ersöz, A. (2010). Türk atasözleri ve deyimlerinde kadına yönelik toplumsal cinsiyet rolleri. Gazi Türkiyat Dergisi. 6. 167-181.

Güzel, E. (2014). Toplumsal cinsiyete dayalı ayrımcılık ve medyanın rolü. Global Media Journal. 4/8. 185-189. 
Hamilton, M. C., Anderson, D., Broaddus, M., Young, K. (2006). Gender stereotyping and under- representation of female characters in 200 popular children's Picture books: A twenty-first century update. Sex Roles. 55. 757-765. http://dx.doi.org/10.1007/s11199-006-9128-6

Kalaycı, N. (2015). Toplumsal cinsiyet eşitliği açısından bir çizgi film çözümlemesi: Pepee. Eğitim ve Bilim. $40-177$. 243-270. http://dx.doi.org/10.15390/EB.2015.3836

Kan, D. (2012). Yeni medya aracı bilgisayar oyunlarında toplumsal cinsiyetin inşası. The Turkish Online Journal of Design, Art and Communication. 2/4. 52-60. http://dx.doi.org/10.7456/10204100/009

Kanat Soysal, Ö. (2011). Türk çocuk edebiyatında kahramanın tanıklığında kadın imgesi (1980-2010 örneği). 3. Ulusal Çocuk ve Gençlik Edebiyatı Sempozyumu içinde (s. 635-640). Ankara: Ankara Üniversitesi.

Karatay, H. (2011). Transfer of values in the Turkish and Western children's literary works: Character education in Turkey. Educational Research and Reviews, 6/6. 472-480.

Kırbaşoğlu Kılıç, L. ve Eyüp, B. (2011). İlköğretim Türkçe ders kitaplarında ortaya çıkan toplumsal cinsiyet rolleri üzerine bir inceleme. ODÜ Sosyal Bilimler Enstitüsü Sosyal Bilimler Araştırmaları Dergisi. 2/3. 129-148.

Kırıtoğlu Özdil, S. (2011). Miyase Sertbarut'un “Kabiland'ın Kobayları” adlı yapıtıyla Christine Nostlinger'in “Kim Takar Salatalık Kralı" adlı yapıtının karakter çevreleri bakımından incelenmesi. 3. Ulusal Çocuk ve Gençlik Edebiyatı Sempozyumu içinde (s. 411-422). Ankara: Ankara Üniversitesi.

Kuzgun, Y., Sevim, S. (2004). Kadınların çalışmasına karşı tutum ve dini yönelim arasındaki ilişki. Ankara Üniversitesi Eğitim Bilimleri Dergisi. 37/1. 14-27. http://dx.doi.org/10.1501/Egifak_0000000088

Miles, M. B. ve Huberman, A. M. (1994). Qualitative data analysis: An Expended Sourcebook. California: SAGE Publications.

Ostergaard, L. (1992). “Gender”, Gender and Development. A Practical Guide içinde (Derlem: Lise Ostergaard) Londra ve Newyork: Routledge. (1-10).

Özçatal, E. Ö. (2011). Ataerkillik, toplumsal cinsiyet ve kadının çalışma yaşamına katılımı. Çankırı Karatekin Üniversitesi İktisadi ve İdari Bilimler Fakültesi Dergisi. 1/1. 21-39.

Özdemir, M. (2010). Türkiye’deki reklamlarda toplumsal cinsiyet ve sunumu. Milli Folklor Dergisi. 88. $101-111$.

Özkan, B. ve Gündoğdu, A. E. (2011). Toplumsal cinsiyet bağlamında Türkçede atasözleri ve deyimler. Turkish Studies. 6/3. 1133-1147.

Özkan, R. (2013). İlköğretim ders kitaplarında kadın figürü. The Journal of Academic Social Science Studies. $6 / 5$. 617-631. http://dx.doi.org/10.9761/JASSS1567

Powell, G.N. ve Greenhause J. H. (2010). Sex, gender and decisions at the family- work interface . Journal of Management. 36/4. 1011-1039. http://dx.doi.org/10.1177/0149206309350774

Püsküllüoğlu, A. (1994). Arkadaş Türkçe sözlük. Arkadaş Yayınevi: Ankara.

Seçgin, F. ve Tural, A. (2011). Sınıf öğretmenliği bölümü öğretmen adaylarının toplumsal cinsiyet rollerine ilişkin tutumlar1. e-Journal of New World Sciences Academi Education Sciences. 6/4. 2446-2458.

Sever, S. (2010). Çocuk ve edebiyat. Tudem Yayınları: İzmir.

Şafak, Ş., Çopur, Z. ve Özkan, M. (2006). Çocukların evle ilgili faaliyetlere harcadıkları zamanın incelenmesi. www.sdergi.hacettepe.edu.tr/sszcmao.pdf (erişim tarihi: 05.11.2015).

Tietz, W. M. (2007). Women and man in accounting textbooks: exploring the hidden curriculum. Issues in Accounting Education. 22/3. 459-480. http://dx.doi.org/10.2308/iace.2007.22.3.459

Vannicopulou, A. (2004). Resimli çocuk kitaplarında kadın karakterler (Çev. Dilek Çiftçi Yeşiltuna). Ege Eğitim Dergisi. 5/2. 65-73.

Vefikuluçay, D., Zeyneloğlu, S., Eroğlu, K. ve Taşkın, L. (2007). Kafkas üniversitesi son sınıf öğrencilerinin toplumsal cinsiyet rollerine ilişkin bakış açıları. Hacettepe Üniversitesi Hemşirelik Yükseokulu Dergisi. $14 / 2$. 26-38.

Yıldırım, A. ve Şimşek, H. (2011). Sosyal bilimlerde nitel araştırma yöntemleri. Seçkin Yayıncılık: Ankara.

Yogev, Ş. P. (2006). Ergenlerde toplumsal cinsiyetin kazanılması aile, okul ve arkadaş etkisi. Yayımlanmamış yüksek lisans tezi. Ankara Üniversitesi, Ankara.

Zivtçi, F. (2006). Çocuk kitaplarında kahramanın yeri ve önemi. 2. Ulusal Çocuk ve Gençlik Edebiyatı Sempozyumu içinde (s. 245-247). Ankara: Ankara Üniversitesi. 